\title{
TRYPTOPHAN DERIVATIVES, PHENOLIC COMPOUNDS AND ANTIOXIDANT POTENTIAL OF SOME WILD TANACETUM TAXA FROM TURKEY
}

\author{
EMEL DIRAZ-YILDIRIM ${ }^{a},{ }^{*}$, SENGUL KARAMAN", \\ MUHITTIN KULAK ${ }^{b}$, AHMET ILCIM ${ }^{c}$
}

\begin{abstract}
The important molecule tryptophan and its derivatives serotonin and melatonin have vital functions in human and plant biosystem. Recent reports claimed these molecules and parthenolide may also have a role in COVID-19 treatments. Herewith the study, contents of chlorogenic acid, cynarin, quinic acid, parthenolide, and tryptophan derivatives in leaf and flowers of seven species of Tanacetum from Turkey were examined using HPLC. The methanolic extracts of the species were also screened for their total phenolic content and DPPH scavenging activity. Regarding to HPLC data, the highest amount of chlorogenic acid and cynarin were detected in $T$. cilicicum, quinic acid in $T$. densum subsp. amani and parthenolide in T. argenteum subsp. argenteum leaves. Also, the highest amount of tryptophan and serotonin were estimated in T. argenteum subsp. argenteum. Melatonin content was highest in $T$. densum subsp. amani. All Tanacetum species exhibited potent antioxidant activities. T. densum subsp. amani (Afşin) flowers had higher DPPH activity than control group BHT and T. cilicicum leaves and flowers had the highest total phenolic content. Herewith, phenolic profiles of $T$. argenteum subsp. argenteum, T. armenum and T. densum subsp. amani and tryptophan derivates of the species were reported for the first time.
\end{abstract}

Keywords: Tanacetum, parthenolide, antioxidant activity, tryptophan, serotonin, melatonin

\section{INTRODUCTION}

The genus Tanacetum $\mathrm{L}$. belonging to Asteraceae (Compositae) family includes over 200 species and is widespread in many countries of North America, Asia and Europe [1]. In Turkey, 61 taxa of Tanacetum exhibit

a Kahramanmaras Sutcu Imam University, Science and Letter Faculty, Biology Department, 46100, Kahramanmaraş, Turkey

b Department of Herbal and Animal Production, Vocational School of Technical Sciences, Igdir University, 76000, Igdir, Turkey

c Mustafa Kemal University, Science and Letter Faculty, Biology Department, 31060, Hatay, Turkey

* Corresponding author: emeldiraz@hotmail.com 
distribution and 24 of them are endemic [2]. Tanacetum taxa has been widely used as medicinal plants over 2000 years due to their bitter substances, sesquiterpene lactones, resins, flavonoids, coumarins, tannic acid, essential oils. The plants have been well-documented to exhibit antimicrobial, antibacterial, antioxidant, expectorants, antiseptic vermifuges, insect-repelling and spasmolytic effects [1,3,4]. Of the species among Tanacetum, $T$. parthenium (feverfew) and $T$. vulgare (tansy) are the common species.

T. parthenium was used in treatment for ailments of the nervous system based on anecdotal and historical evidence. In 1978, British health magazine reported that feverfew leaves had chronic relieving effects and the plant gained popularity as a phytomedicine. The main molecule parthenolide was isolated from $T$. parthenium shoots and amount of the molecule was changed among $0.1-0.2 \%$ as approved pharmacologically active. Also, anticancer and antiinflammatory activities of parthenolide have been shown $[5,6]$. Recent studies regarding chemical probe development from parthenolide showed that parthenolide-induced microtubule modulation and the currently characterized tubulin carboxypeptidase enzymes involved in nerve (re)growth, cardiac muscle cell function, and metastasis development [7]. Bahrami et al. claimed that parthenolide may be one of the herbal candidates for clinical evaluation of COVID-19 with a support of reduced mortality. Parthenolide reduced L-1, IL-2, IL-6, IL-8, and TNF-a production pathways which IL-6 in cytokine storm has significant role diabetes mellitus, and cardiovascular diseases as principal comorbidities [8].

The other active compound melatonin ( $\mathrm{N}$-acetyl-5-methoxytryptamine) is synthesized from the amino acid L-tryptophan via serotonin (5-Hydroxytryptamine). Therefore, L-tryptophan is the precursor for melatonin and serotonin [9]. Murch et al. highlighted that chronic migraine headaches are associated with lower circulation levels of melatonin [3]. Furthermore, melatonin was proved to be associated with a number of nervous diseases such as epilepsy, insomnia, depression, Alzheimer, Parkinson's illness and regulating circadian rhythm, improving immunity and anti-aging $[10,11]$. In a recent study, in COVID-19 patients, the expression of genes part of tryptophan metabolism was increased, so that tryptophan-rich sources could be beneficial for COVID-19 [12]. Reasearches about melatonin, serotonin and tryptophan content of foods, drinks and medicinal plants is fast increasing because requirement to synthetic melatonin is rising. According to a report published by Transparency Market Research entitled "Melatonin Market for Food \& Beverages, Dietary Supplements, Medicine and Other Applications", the global demand of synthetic melatonin was valued at USD 504 million in 2012 and was expected to reach USD 1300 million in 2019, the latter involves about 4000 tons of synthetic melatonin [13]. Considering that the consumption of rich phytomelatonin 
foods increases the level of melatonin in humans, it is inevitable that the need for phytomelatonin supplements will increase. Phytomelatonin is a potential option to substitute synthetic melatonin.

Of the studies, Murch et al. [3] investigated the melatonin level of some medicinal plants and detected rich melatonin content in feverfew. Feverfew is recommended as a migraine prophylactic since clinical researches have approved its potent effect against headaches and migraine [14]. Also, serotonin agonists were used in migraine treatments [15]. Hitherto, no documents regarding serotonin and tryptophan content of Tanacetum taxa have been reported. The present study was designed to investigate phenolics profile, antioxidant activity, parthenolide, tryptophan, serotonin and melatonin content of seven wild Tanacetum taxa ( $T$. argenteum subsp. argenteum, $T$. armenum, $T$. cadmeum subsp. orientale, T. cilicicum, $T$. densum subsp. amani, $T$. kotschyi, T. nitens) for first time.

\section{RESULTS AND DISCUSSION}

\section{HPLC-UV analyses of some secondary metabolites in Tanacetum taxa}

The distribution of chlorogenic acid, cynarin, quinic acid and parthenolide in leaf and flowers of some Tanacetum species has been reported herein. The quantitative analysis of the individual compounds in the polar extracts was performed using HPLC-UV and the results were represented in Table 1 and representative HPLC-UV chromatograms were given in Figure 1.

The compounds were confirmed by comparing the retention times with the standards. Herewith the results, the contents of the compounds exhibited significant differences according to the species and organs $(p<0.01)$. For the present study, $T$. argenteum subsp. argenteum was collected lately of flowering period and the plant material of $T$. cadmeum subsp. orientale and $T$. nitens were not enough for all biochemical analyses. Therefore, flowers of $T$. argenteum subsp. argenteum and other two taxa were not screened for their chlorogenic acid, cynarin, quinic acid and parthenolide contents. Of the species, chlorogenic acid and cynarin were detected highest in $T$. cilicicum (15.61 \pm 0.03 and $19.68 \pm 0.14 \mathrm{mg} / \mathrm{g} \mathrm{DW}$, respectively) leaves and quinic acid in T. densum subsp. amani (Afşin) $(84.82 \pm 0.45 \mathrm{mg} / \mathrm{g} \mathrm{DW}$ ) leaves. Quinic acid was the most abundant secondary metabolite identified herein $(19.27 \pm 2.30$ to $84.82 \pm 0.45 \mathrm{mg} / \mathrm{g} \mathrm{DW}$ in leaves and $12.36 \pm 0.30$ to $31.73 \pm 0.20 \mathrm{mg} / \mathrm{g} \mathrm{DW}$ in flowers). Regarding parthenolide content, the contents were higher in leaves than those in flowers. The highest parthenolide content was determined in $T$. argenteum subsp. argenteum leaves (1.48\%). In addition, $T$. densum subsp. amani collected from two different locations (Afşin and Ahırdağı) exhibited significant differences concerned with metabolites reported herein. In the 
previous studies, chlorogenic acid content in $T$. parthenium were reported to be 2.13-7.62 ppm [16], 80-100 mg/g [17], 0.286-2.976 mg/g [18], $6.45 \mathrm{~g} / \mathrm{kg}$ [19], and $0.784 \%$ [20]. In T. cilicicum, chlorogenic acid content was found as $2.30 \mu \mathrm{g} / \mathrm{mg}$ [21]. Also, cynarin (1.48-7.49 ppm) and quinic acid (4-5.5 ppm) in $T$. parthenium were reported by Wu et al. [16]. The present results are similar to those values of previous studies.

Table 1. Phenolic compounds and parthenolide amount of Tanacetum taxa

\begin{tabular}{|c|c|c|c|c|c|c|c|c|}
\hline \multirow[b]{2}{*}{ Taxa } & \multicolumn{2}{|c|}{$\begin{array}{l}\text { Chlorogenic } \\
\text { acid (mg/g) }\end{array}$} & \multicolumn{2}{|c|}{$\begin{array}{c}\text { Cynarin } \\
\text { (mg/g) }\end{array}$} & \multicolumn{2}{|c|}{$\begin{array}{l}\text { Quinic acid } \\
(\mathrm{mg} / \mathrm{g})\end{array}$} & \multicolumn{2}{|c|}{$\begin{array}{l}\text { Parthenolide } \\
\text { (mg/100g) }\end{array}$} \\
\hline & ${ }^{* *}$ Leaf & **Flower & ${ }^{* *}$ Leaf & **Flower & **Leaf & ${ }^{* \star}$ Flower & ${ }^{* *}$ Leaf & **Flower \\
\hline $\begin{array}{l}\text { T. argenteum } \\
\text { subsp. argenteum }\end{array}$ & $\begin{array}{l}4.31 \pm \\
0.02^{c}\end{array}$ & ns & $\begin{array}{l}4.89 \pm \\
0.02^{b}\end{array}$ & ns & \begin{tabular}{|c|}
$42.51 \pm$ \\
$1.37^{\mathrm{b}}$
\end{tabular} & ns & $\begin{array}{l}1.480 \pm \\
0.050^{\mathrm{a}}\end{array}$ & ns \\
\hline T. armenum & $\begin{array}{l}3.22 \pm \\
0.01^{d}\end{array}$ & $\begin{array}{l}2.65 \pm \\
0.09^{b}\end{array}$ & $\begin{array}{l}0.22 \pm \\
0.01^{f}\end{array}$ & $\begin{array}{l}0.60 \pm \\
0.03^{d}\end{array}$ & \begin{tabular}{|c|}
$29.47 \pm$ \\
$1.24^{\mathrm{d}}$ \\
\end{tabular} & $\begin{array}{c}31.73 \pm \\
0.20^{\mathrm{a}}\end{array}$ & $\begin{array}{l}0.036 \pm \\
0.001^{d}\end{array}$ & \begin{tabular}{|l|}
$0.010 \pm$ \\
$0.005^{\mathrm{c}}$
\end{tabular} \\
\hline T. cilicicum & $\begin{array}{c}15.61 \pm \\
0.03^{a}\end{array}$ & $\begin{array}{l}2.38 \pm \\
0.05^{\mathrm{c}}\end{array}$ & $\begin{array}{c}19.68 \pm \\
0.14^{\mathrm{a}}\end{array}$ & $\begin{array}{l}7.96 \pm \\
0.04^{b}\end{array}$ & \begin{tabular}{|l|}
$19.27 \pm$ \\
$2.30^{\mathrm{e}}$
\end{tabular} & $\begin{array}{l}23.78 \pm \\
2.30^{c}\end{array}$ & $\begin{array}{l}0.117 \pm \\
0.009^{c}\end{array}$ & $\begin{array}{l}0.020 \pm \\
0.002^{\mathrm{b}}\end{array}$ \\
\hline $\begin{array}{l}\text { T. densum subsp. } \\
\text { amani (Afşin) }\end{array}$ & $\begin{array}{l}13.91 \pm \\
0.18^{\mathrm{b}}\end{array}$ & $\begin{array}{l}0.32 \pm \\
0.04^{d}\end{array}$ & $\begin{array}{l}3.69 \pm \\
0.01^{c}\end{array}$ & $\begin{array}{l}0.69 \pm \\
0.02^{d}\end{array}$ & \begin{tabular}{|c|}
$84.82 \pm$ \\
$0.45^{\mathrm{a}}$
\end{tabular} & $\begin{array}{c}27.55^{ \pm} \\
0.24^{\mathrm{b}}\end{array}$ & $\begin{array}{l}0.120 \pm \\
0.000^{c}\end{array}$ & \begin{tabular}{|l|}
$0.010 \pm$ \\
$0.005^{\mathrm{c}}$
\end{tabular} \\
\hline $\begin{array}{l}\text { T. densum subsp. } \\
\text { amani (Ahır Mount) }\end{array}$ & $\begin{array}{l}2.86 \pm \\
0.02^{\mathrm{e}} \\
\end{array}$ & $\begin{array}{l}0.81 \pm \\
0.02^{\mathrm{e}}\end{array}$ & $\begin{array}{l}1.73 \pm \\
0.08^{\mathrm{e}}\end{array}$ & $\begin{array}{l}1.57 \pm \\
0.05^{\mathrm{c}}\end{array}$ & \begin{tabular}{|c|}
$38.32 \pm$ \\
$0.50^{\mathrm{c}}$ \\
\end{tabular} & $\begin{array}{l}29.34 \pm \\
0.04^{\mathrm{ab}}\end{array}$ & $\begin{array}{l}0.035 \pm \\
0.002^{\mathrm{d}}\end{array}$ & \begin{tabular}{|l|}
$0.018 \pm$ \\
$0.001^{\mathrm{b}}$ \\
\end{tabular} \\
\hline T. kotschyi & $\begin{array}{l}1.75 \pm \\
0.02^{f}\end{array}$ & $\begin{array}{l}7.06 \pm \\
0.07^{a}\end{array}$ & $\begin{array}{l}2.12 \pm \\
0.08^{d}\end{array}$ & \begin{tabular}{|c|}
$11.14 \pm$ \\
$0.07^{\mathrm{a}}$
\end{tabular} & $\begin{array}{c}27.80 \pm \\
1.30^{\mathrm{d}}\end{array}$ & $\begin{array}{c}12.36 \pm \\
0.30^{d}\end{array}$ & $\begin{array}{l}0.200 \pm \\
0.050^{b}\end{array}$ & \begin{tabular}{|l}
$0.080 \pm$ \\
$0.000^{a}$
\end{tabular} \\
\hline
\end{tabular}

The data were statistically significant as compared with the control $\left({ }^{* *} p<0.01\right)$; letters indicate the significantly differing content of metabolites one from other taxa according Duncan test, ns: not studied

For parthenolide content of Tanacetum species, Orhan Erdoğan et al. [22], determined the parthenolide content of $T$. argenteum subsp. argenteum (2.261-1.585\%), T. parthenium (0.186-0.279\%, 0.231-0.505\%) and T. densum subsp. laxum (0.832-0.090\%) in leaves and flowers, respectively but parthenolide was not quantified in T. cilicicum. Furthermore, Özbilgin et al. [23], reported the parthenolide content in $T$. argenteum subsp. argenteum as $242.66 \mu \mathrm{g} / 100 \mathrm{mg}$ but parthenolide was not detected in $T$. densum subsp. sivasicum. As seen in previous studies, T. argenteum subsp. argenteum showed highest parthenolide content. These results support our findings. Along with the study, parthenolide in $T$. cilicicum and $T$. densum subsp. amani were reported. The availability or detection of the compounds might be attributed to the extraction methods, solvents, sampling periods or time of the plant vegetation. 

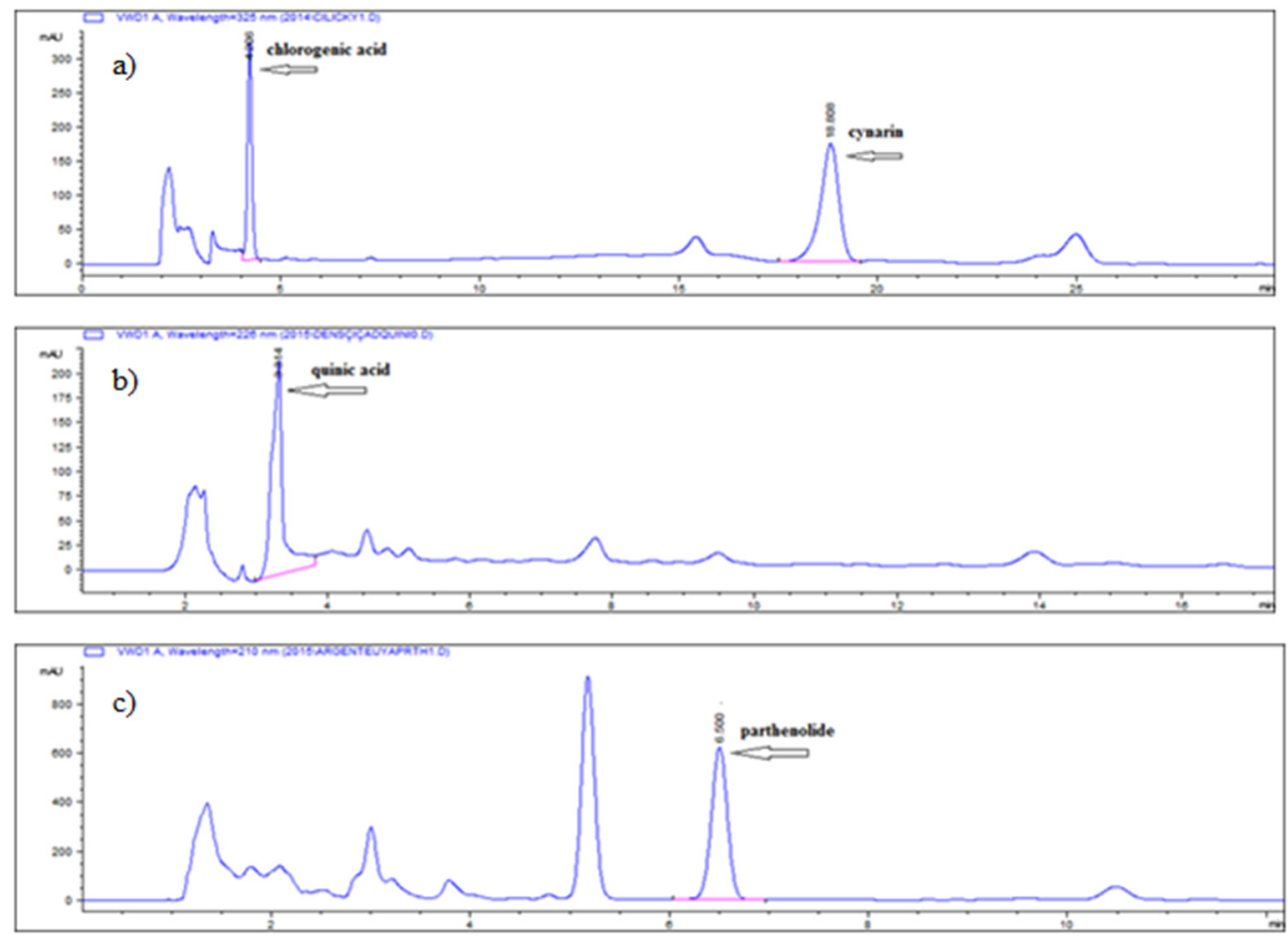

Figure 1. HPLC. a) Chromatograms of chlorogenic acid, cynarin; b) Chromatograms of quinic acid; c) Chromatograms of parthenolide.

\section{HPLC analyses of tryptophan derivates in Tanacetum taxa}

The concentrations of tryptophan, serotonin and melatonin in leaf and flowers of seven Tanacetum taxa were reported herein. The quantitative analysis of the individual compounds in the polar extracts was performed using HPLC-UV and the results were represented in Table 2 and representative HPLC-UV chromatograms were given in Figure 2.

Peak identifications were accomplished by comparing retention time of tryptophan, serotonin and melatonin in a standard solution with the chromatograms obtained from plant extract. HPLC chromatographic peaks for standard solutions and $T$. argenteum subsp. argenteum leaf extract peaks were overlapped and given in Figure 2a. These metabolites amount differed not only inter-specific but also among plant tissue of the same species $(p<0.01)$. Content of tryptophan varied from 13.480-169.57 ppm in leaves and 11.56$63.02 \mathrm{ppm}$ in flowers. Of the species, T. argenteum subsp. argenteum had 
Table 2. Tryptophan, serotonin and melatonin content of Tanacetum taxa

\begin{tabular}{|l|c|c|c|c|c|c|}
\hline & \multicolumn{2}{|c|}{ Tryptophan (ppm) } & \multicolumn{2}{c|}{ Serotonin (ppm) } & \multicolumn{2}{c|}{ Melatonin (ppm) } \\
\hline Taxa & Leaf $^{\star *}$ & Flower $^{* *}$ & Leaf $^{* *}$ & Flower $^{* *}$ & Leaf* $^{\star *}$ & Flower $^{* *}$ \\
\hline T. argenteum subsp. & $169.57 \pm$ & $40.66 \pm$ & $78.20 \pm$ & $79.78 \pm$ & $5.48 \pm$ & $2.57 \pm$ \\
argenteum & $1.40^{\mathrm{a}}$ & $0.80^{\mathrm{c}}$ & $0.79^{\mathrm{a}}$ & $0.69^{\mathrm{a}}$ & $0.50^{\mathrm{c}}$ & $0.13^{\mathrm{d}}$ \\
\hline T. armenum & $13.480 \pm$ & $63.02 \pm$ & $17.88 \pm$ & $43.88 \pm$ & $5.33 \pm$ & $4.42 \pm$ \\
& $1.30^{\mathrm{f}}$ & $1.78^{\mathrm{a}}$ & $1.90^{\mathrm{f}}$ & $2.87^{\mathrm{d}}$ & $0.20^{\mathrm{c}}$ & $0.30^{\mathrm{c}}$ \\
\hline T. cadmeum subsp. & $20.050 \pm$ & $40.63 \pm$ & $31.04 \pm$ & $17.10 \pm$ & $8.12 \pm$ & $7.02 \pm$ \\
orientale & $2.70^{\mathrm{e}}$ & $0.26^{\mathrm{c}}$ & $0.98^{\mathrm{e}}$ & $0.05^{\mathrm{f}}$ & $0.20^{\mathrm{a}}$ & $0.50^{\mathrm{a}}$ \\
\hline T. cilicicum & $22.360 \pm$ & $11.56 \pm$ & $64.22 \pm$ & $14.34 \pm$ & $4.94 \pm$ & $1.05 \pm$ \\
& $0.30^{\mathrm{e}}$ & $1.10^{\mathrm{f}}$ & $0.30^{\mathrm{b}}$ & $0.60^{\mathrm{g}}$ & $0.20^{\mathrm{c}}$ & $0.20^{\mathrm{f}}$ \\
\hline T. densum subsp. & $157.94 \pm$ & $37.46 \pm$ & $77.81 \pm$ & $71.61 \pm$ & $3.03 \pm$ & $2.39 \pm$ \\
amani (Afşin) & $1.21^{\mathrm{b}}$ & $0.69^{\mathrm{d}}$ & $1.05^{\mathrm{a}}$ & $1.17^{\mathrm{b}}$ & $0.19^{\mathrm{d}}$ & $0.26^{\mathrm{d}}$ \\
\hline T. densum subsp. & $20.200 \pm$ & $36.42 \pm$ & $19.23 \pm$ & $33.21 \pm$ & $8.46 \pm$ & $6.33 \pm$ \\
amani (Ahır M.) & $0.59^{\mathrm{e}}$ & $0.30^{\mathrm{d}}$ & $0.13^{\mathrm{f}}$ & $0.70^{\mathrm{e}}$ & $0.50^{\mathrm{a}}$ & $0.40^{\mathrm{b}}$ \\
\hline T. kotschyi & $31.830 \pm$ & $33.02 \pm$ & $38.18 \pm$ & $42.34 \pm$ & $1.99 \pm$ & $1.45 \pm$ \\
& $0.40^{\mathrm{d}}$ & $1.20^{\mathrm{e}}$ & $0.40^{\mathrm{d}}$ & $0.80^{\mathrm{d}}$ & $0.10^{\mathrm{e}}$ & $0.10^{\mathrm{e}}$ \\
\hline T. nitens & $64.470 \pm$ & $58.60 \pm$ & $47.46 \pm$ & $59.50 \pm$ & $6.52 \pm$ & $6.27 \pm$ \\
& $0.80^{\mathrm{c}}$ & $0.70^{\mathrm{b}}$ & $1.20^{\mathrm{c}}$ & $1.20^{\mathrm{c}}$ & $0.22^{\mathrm{b}}$ & $0.30^{\mathrm{b}}$ \\
\hline
\end{tabular}

The data were statistically significant as compared with the control $\left({ }^{\star *} p<0.01\right)$; letters indicate the significantly differing content of metabolites one from other taxa according Duncan test
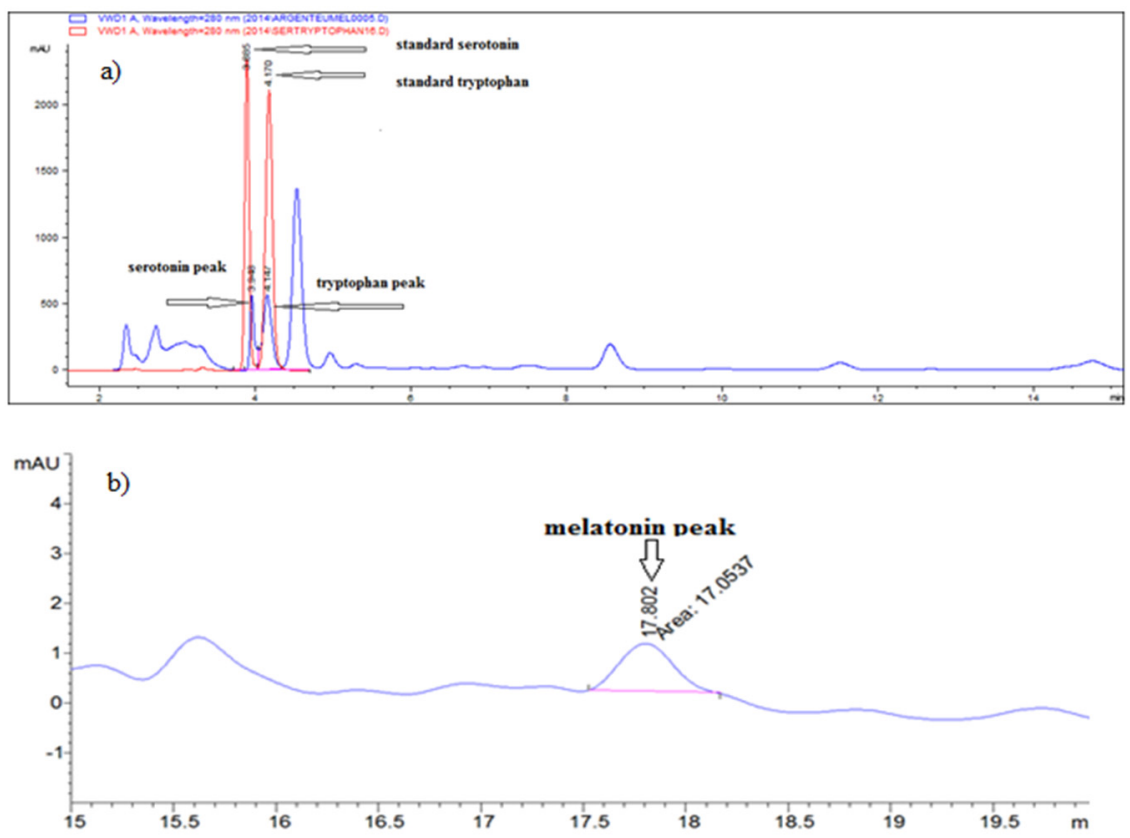

Figure 2. a) Chromatograms of tryptophan and serotonin standard solution and plant extract in HPLC chromatogram, b) Melatonin peak of the $T$. cilicium leaves extract in HPLC chromatogram 
the highest content of tryptophan in their leaves $(169.57 \pm 1.40 \mathrm{ppm} \mathrm{DW})$ whereas the lowest content was determined in $T$. armenum $(13.480 \pm 1.30$ ppm DW). However, the highest content of tryptophan in flower was found in $T$. armenum $(63.02 \pm 1.78 \mathrm{ppm} \mathrm{DW})$. Furthermore, $T$. argenteum subsp. argenteum had the highest content of serotonin in both leaves $(78.20 \pm 0.79$ ppm DW) and flowers (79.78 $\pm 0.69 \mathrm{ppm}$ DW). Melatonin content was found at low levels using HPLC-UV. In order to confirm the reliability of the results, further LC-MS/MS analyses were performed. In the previous studies, Liquid chromatography-Mass Spectrometry (LC-MS/MS) is considered to be the effective method of detecting melatonin in plant material/food [24, 25]. On the basis of the mass fragmentation interpretation, standard melatonin $(\mathrm{m} / \mathrm{z} 233)$ was identified by LC/MS-MS (Figure 3a).
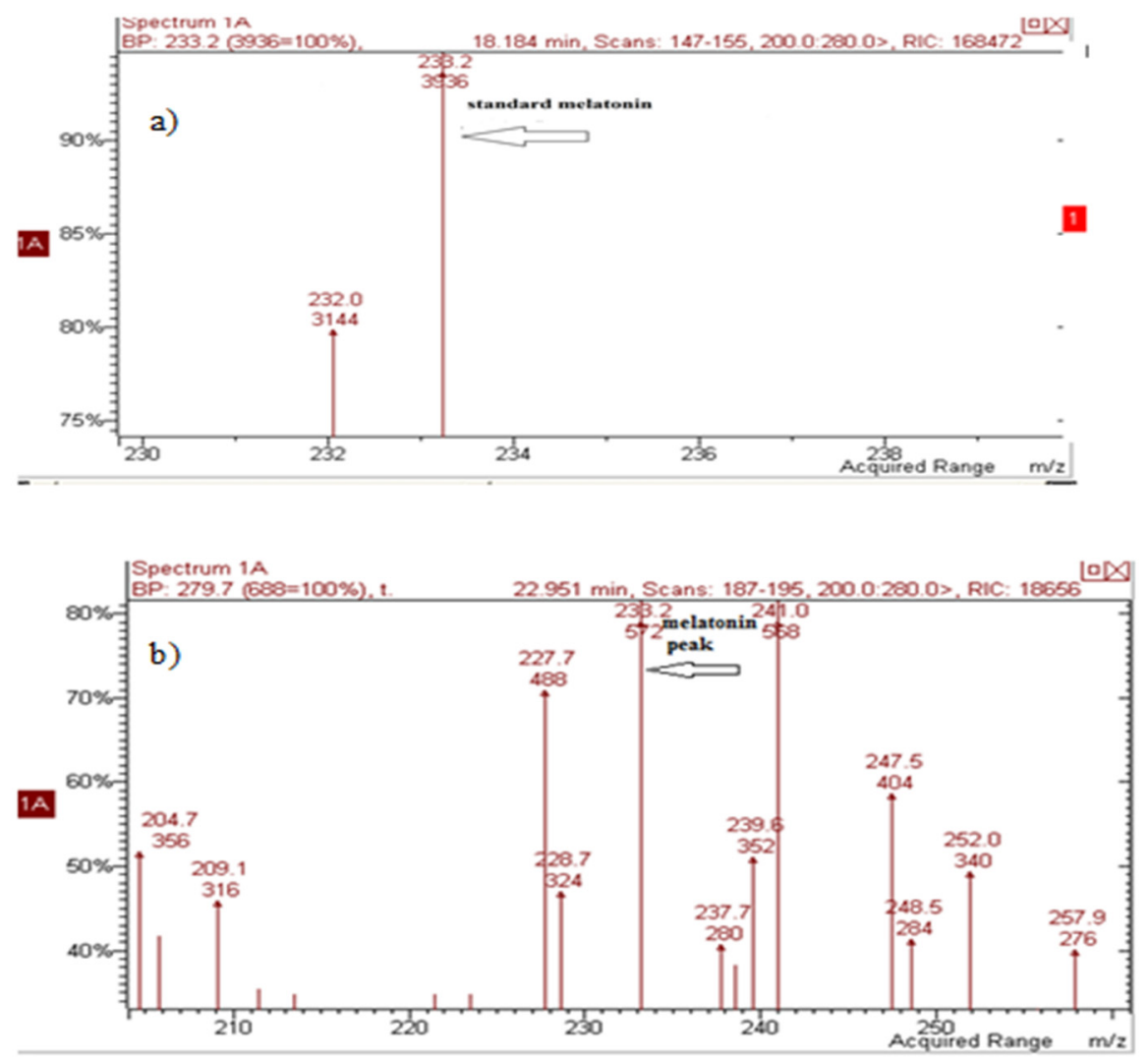

Figure 3. Mass spectra of a) melatonin peak in standard solution, b) of melatonin peak in plant extract 
The LC/MS-MS spectra of $T$. armenum extracts were given in Figure $3 \mathrm{~b}$ and melatonin peak in HPLC chromatogram of the $T$. cilicicum leaves was given in Figure 2b. Melatonin level was detected higher in leaves than in flowers in all taxa but serotonin and tryptophan levels exhibited differences. Melatonin content was found higher in T. densum subsp. amani (Ahır Mount location) leaves $(8.46 \mathrm{ppm})$ and flowers $(6.33 \mathrm{ppm})$ than other taxa. $T$. densum subsp. amani collected from Afşin (3.03 ppm in leaves, $2.39 \mathrm{ppm}$ in flowers). Although Ahır Mount and Afşin had similar altitudes, ecological characteristics of the locations exhibited differences. While Ahır Mountain belongs to Mediterranean floristic region, Afşin location belongs to İran-Turan floristic region. Differences in time of harvest and environmental impact during plant growth and development cause variations in melatonin and serotonin levels $[26,27]$.

The amounts of serotonin, tryptamine, and tyramine were reported in several commonly consumed fruits and vegetables [28]. In the study by Huang and Mazza [26], serotonin content was ranged from 1.800 to 221.900 $\mathrm{ng} / \mathrm{g}$ and melatonin levels varied between 0.006 and $34.500 \mathrm{ng} / \mathrm{g}$ in some edible plants. Chen et al. [29], determined that the melatonin levels ranged from $10 \mathrm{ng}-3.771 \mu \mathrm{g} / \mathrm{g}$ among 108 chinese medicinal plant. Murch et al. [3], used different dried techniques for $T$. parthenium and detected melatonin level among 1.37-2.45 $\mu \mathrm{g} / \mathrm{g}$. Ansari et al. [30], used different analytical and extraction methods for $T$. parthenium leaves and determined the melatonin level as $1010.6-2086.9 \mathrm{ng} / \mathrm{g}$. Pérez-Llamas et al. [13], detected melatonin content of a herbal mix and improving a final product from mix as $5.5 \mu \mathrm{g} / \mathrm{g}$, $7.2 \mathrm{mg} / \mathrm{g}$ respectively. Of the examined studies, the quantification methods were different and therefore the documented results regarding the content of the metabolites might be not consistent [26]. Herewith, in addition to the analytical techniques, the differences might be attributed to the ecological conditions, stress factors, genetic factors and harvesting time.

\section{Antioxidant activity and phenolics content of Tanacetum taxa}

The percentage of DPPH scavenging activity and total phenolics content of Tanacetum taxa were given in Table 3 . The species showed significant differences with respect to antioxidant potential of leaves and flowers $(p<0.01)$. As seen in Table 3, Tanacetum taxa had potent antioxidant activity. T. densum subsp. amani (Afşin) $(96.20 \%$ ) flowers were more effective than those in control group BHT. DPPH activities of flowers were higher than leaves. $T$. cilicicum had the highest total phenolic compounds in their leaves (84.01 mg GAE/g). Leaves of the taxa contained more total phenolics content than those of flowers except $T$. kotschy. 
TRYPTOPHAN DERIVATIVES, PHENOLIC COMPOUNDS AND ANTIOXIDANT POTENTIAL ...

Table 3. Antioxidant activity and total phenolic contents of Tanacetum species

\begin{tabular}{|l|c|c|c|c|}
\hline \multicolumn{2}{|c|}{ DPPH Activity (\%) } & \multicolumn{2}{c|}{ Total Phenolics (mg/g GAE) } \\
\hline \multicolumn{1}{|c|}{ Taxa } & ${ }^{* *}$ Leaf & ${ }^{* *}$ Flower & ${ }^{* *}$ Leaf & ${ }^{* *}$ Flower \\
\hline$T$. argenteum subsp. argenteum & $95.60 \pm 0.05^{\mathrm{a}}$ & $\mathrm{ns}$ & $51.79 \pm 0.11^{\mathrm{c}}$ & $\mathrm{ns}$ \\
\hline$T$. armenum & $93.50 \pm 0.50^{\mathrm{bc}}$ & $95.66 \pm 1.50^{\mathrm{ab}}$ & $36.79 \pm 3.70^{\mathrm{d}}$ & $28.58 \pm 1.2^{\mathrm{c}}$ \\
\hline T. cilicicum & $95.00 \pm 0.00^{\mathrm{ab}}$ & $96.00 \pm 0.01^{\mathrm{a}}$ & $84.01 \pm 3.50^{\mathrm{a}}$ & $46.63 \pm 1.9^{\mathrm{b}}$ \\
\hline T. densum subsp. amani (Afşin) & $95.80 \pm 0.08^{\mathrm{a}}$ & $96.20 \pm 0.58^{\mathrm{a}}$ & $65.52 \pm 2.26^{\mathrm{b}}$ & $16.58 \pm 1.5^{\mathrm{d}}$ \\
\hline $\begin{array}{l}\text { T. densum subsp. amani (Ahır } \\
\text { Mount) }\end{array}$ & $92.33 \pm 1.52^{\mathrm{c}}$ & $95.16 \pm 0.20^{\mathrm{b}}$ & $25.39 \pm 2.48^{\mathrm{e}}$ & $17.88 \pm 2.8^{\mathrm{d}}$ \\
\hline T. kotschyi & $92.30 \pm 0.50^{\mathrm{c}}$ & $95.00 \pm 0.01^{\mathrm{b}}$ & $33.50 \pm 1.30^{\mathrm{f}}$ & $53.36 \pm 2.9^{\mathrm{a}}$ \\
\hline BHT (control) & $96.00 \pm 0.00^{\mathrm{a}}$ & $96.00 \pm 0.00^{\mathrm{a}}$ & & \\
\hline
\end{tabular}

The data were statistically significant as compared with the control $\left.{ }^{* *} p<0.01\right)$; letters indicate the significantly differing content of metabolites one from other taxa according Duncan test, ns: not studied

As in previous studies, Savcl et al. [31], reported some Tanacetum species showed similar DPPH activity with BHT. Arıtuluk et al. [4], determined that percentage of DPPH scavenging activity of aerial parts of $T$. armenum and $T$. cilicicum were $81.67 \%$ and $77.61 \%$, respectively, whereas total phenolic contents of aerial parts of $T$. armenum and $T$. cilicicum were $58.86 \mathrm{mg} \mathrm{GAE} / \mathrm{g}$ and $33.14 \mathrm{mg} \mathrm{GAE} / \mathrm{g}$, respectively. Esmaeili et al. [32], reported that $T$. kotschyi showed high antioxidant activity and included total phenolic compounds as $44.40 \mathrm{mg} \mathrm{GAE} / \mathrm{g}$ while $90 \%$ DPPH scavenging activities of $T$. kotschyi were reported [33].

Gecibesler et al. [21], determined the total phenolic content of $T$. cilicicum among 99.53-268.02 mg GAE/g. Tepe and Sökmen [34], Emre [35], investigated the amount of total phenolics and antioxidant activity of $T$. densum subsp.

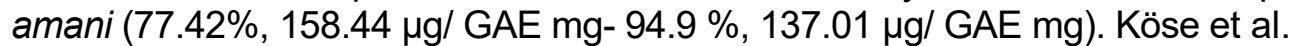
[36], reported total phenolic amount as $63 \mathrm{mg} / \mathrm{GAE} \mathrm{g}$ in Tanacetum argenteum (Lam.) willd. subsp. flabellifolium. As it can be seen from the previous studies revealing the antioxidant potential of Tanacetum species showed similarity with our results and these wild species showed remarkable antioxidant activity. Higher activities might be attributed to low-temperature at higher altitude and subsequently increased rate of biosynthesis of antioxidant molecules [37]. As well as, Zengin et al. [38], declared that extraction techniques significantly effected phenol and flavonoid content of Tanacetum parthenium. 


\section{Principal component analysis}

The discrimination can be evaluated from the principal component analysis scores plot between different Tanacetum taxa using identified metabolites identified herein as shown in Figure 4. With this visualization, the more expressed metabolites in plant species are located in the same area of the graph coupled with similar metabolite contents. Discrimination was shown on the plotted scores, where two principal components accounted for $76.59 \%$ of total variance. The first axis and second axis explained $39.26 \%$ and $37.33 \%$ of total variance. According to the results, $T$. armenum and $T$. densum (Ahır Mount), T. densum (Afşin) and T. cilicicum as well as T. kotschyi corresponded to three groups.

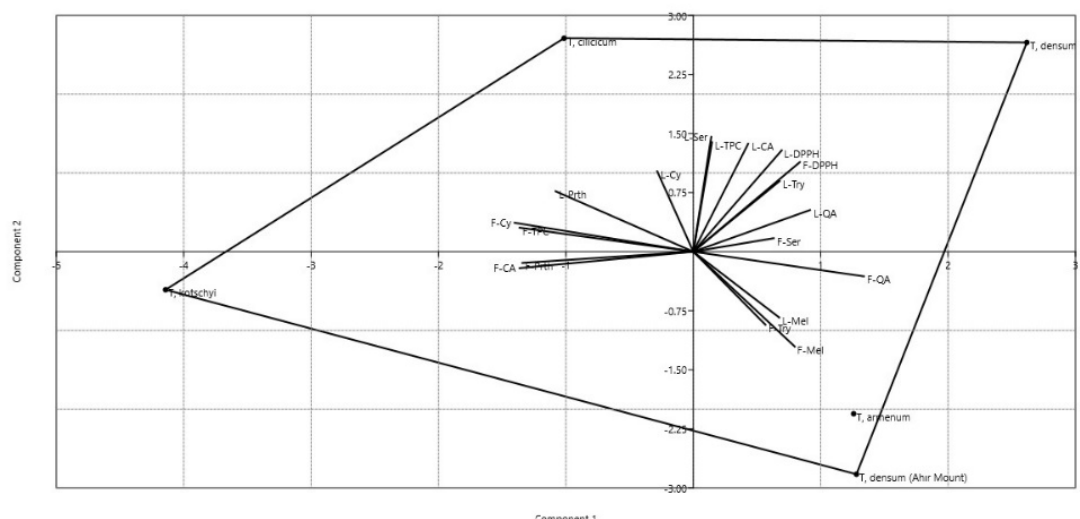

Figure 4. Principal component analysis of Tanacetum taxa

\section{CONCLUSIONS}

Along with the present study, the contents of chlorogenic acid, cynarin, quinic acid and parthenolide were for the first time reported for some Tanacetum species. Cynarin is of the biologically active chemical constituent of artichoke (Cynara scolymus L.), exhibit in potent choleretic, antimicrobial, antioxidant, antiradical, anticholinergic activities [39]. The content of cynarin were reported as $95-529.5 \mathrm{mg} / \mathrm{kg}$ [40], 10.15-0.67 mg/g [41] in artichoke. As our results, especially $T$. cilicicum can be shown as alternative source for cynarin. Of the significant compounds, parthenolide was found in large amounts. In European Pharmacopeia, required percentage of parthenolide was $0.2 \%$. Herein, most of the Tanacetum species included higher amount than required, especially endemic species $T$. argenteum subsp. argenteum and $T$. densum subsp. amani (Afşin). Besides, $T$. argenteum subsp. argenteum had a large amount of tryptophan and serotonin. Furthermore, melatonin level of many taxa was 
higher than those levels in common taxon T. parthenium. For the first time, no studies regarding the levels tryptophan, serotonin and melatonin have been performed in those Tanacetum species in present research hitherto. These components were found at important concentrations. The results obtained from this study demonstrate that these species might be evaluated commercially for their rich amount of biological active components in medicinal, pharmaceuticals and food industry.

\section{EXPERIMENTAL SECTION}

\section{Plant material}

Tanacetum species were collected from Kahramanmaraş city between 2012 and 2013. The plant species were identified by Dr. Ahmet Ilcim using Flora of Turkey and East Aegean Islands [42]. Plant materials, their origins and collection areas were listed in Table 4. The plants were collected at flowering period and then dried at room conditions. T. densum subsp. amani was collected from two different locations, namely Afşin and Ahır Mountain.

Table 4. Wild Tanacetum species along with site of collections and distribution range

\begin{tabular}{|c|c|c|c|c|c|}
\hline Taxa & Diversity & Locality/Habitat & $\begin{array}{l}\text { Collection } \\
\text { date }\end{array}$ & Altitude & $\begin{array}{l}\text { Collection } \\
\text { No }\end{array}$ \\
\hline $\begin{array}{l}\text { T. argenteum (Lam.) Willd } \\
\text { subsp. argenteum (L.) All. }\end{array}$ & Endemic & $\begin{array}{c}\text { Afşin, Güvek } \\
\text { Plateau } \\
\text { calcareous rocks }\end{array}$ & 26.08.2013 & $1800 \mathrm{~m}$ & KSUH 1001 \\
\hline $\begin{array}{l}\text { T. armenum (DC.) Schultz } \\
\text { Bip }\end{array}$ & İran-Turan & $\begin{array}{l}\text { Işık Mountain } \\
\text { calcareous, limy } \\
\text { rocks }\end{array}$ & 11.07.2012 & $2800 \mathrm{~m}$ & KSUH 1002 \\
\hline T. cilicicum (Boiss.) Grierson & $\begin{array}{l}\text { E.Mediterra- } \\
\text { nean } \\
\text { element }\end{array}$ & $\begin{array}{l}\text { Başkonuş } \\
\text { Roadside }\end{array}$ & 19.07.2012 & $1800 \mathrm{~m}$ & KSUH 1003 \\
\hline $\begin{array}{l}\text { T. cadmeum (Boiss.) } \\
\text { Heywood subsp. } \\
\text { orientale Grierson }\end{array}$ & Endemic & $\begin{array}{l}\text { Işık Mountain } \\
\text { calcareous, limy } \\
\text { rocks }\end{array}$ & 09.07.2012 & $2600 \mathrm{~m}$ & KSUH 1004 \\
\hline $\begin{array}{l}\text { T. densum (Lab.) Schultz } \\
\text { Bip. subsp. amani Heywood }\end{array}$ & Endemic & $\begin{array}{l}\text { Ahır Mountain } \\
\text { Yedikuyular } \\
\text { calcareous rocks }\end{array}$ & 28.06.2012 & $1800 \mathrm{~m}$ & KSUH 1005 \\
\hline $\begin{array}{l}\text { T. densum (Lab.) Schultz } \\
\text { Bip. subsp. amani Heywood }\end{array}$ & Endemic & $\begin{array}{c}\text { Afşin, Güvek } \\
\text { Plateau } \\
\text { calcareous rocks }\end{array}$ & 26.08 .2013 & $1800 \mathrm{~m}$ & KSUH 1006 \\
\hline T. kotschyi (Boiss.) Grierson & İran-Turan & $\begin{array}{l}\text { Berit Mountain, } \\
\text { Karagöl Site } \\
\text { calcareous, } \\
\text { limy rocks }\end{array}$ & 11.07.2012 & $3100 \mathrm{~m}$ & KSUH 1007 \\
\hline $\begin{array}{l}\text { T. nitens (Boiss. \&Noë) } \\
\text { Grierson }\end{array}$ & Endemic & $\begin{array}{l}\text { Işık Mountain } \\
\text { calcareous, limy } \\
\text { rocks }\end{array}$ & 09.07.2012 & $2650 \mathrm{~m}$ & KSUH 1008 \\
\hline
\end{tabular}




\section{Chemicals}

All of the analytical grade solvents were purchased from Merck. 2,2Diphenyl-1-picrylhydrazyl (DPPH) was provided from Aldrich, chlorogenic acid (dissolved in ethanol), cynarin (dissolved in methanol), quinic acid (dissolved in dd- $\mathrm{H}_{2} \mathrm{O}$ ), tryptophan (dissolved in warm dd- $\mathrm{H}_{2} \mathrm{O}$ ), serotonin (dissolved in dd- $\mathrm{H}_{2} \mathrm{O}$ with $0.1 \mathrm{M} \mathrm{HCl}$ ) melatonin (dissolved in $80 \%$ methanol), FolinCiocalteu reagent $(2 \mathrm{~N})$, gallic acid and quercetine were obtained from Sigma. Parthenolide was purchased from Cayman (dissolved with dimethyl sulfoxide), BHT (Butylated Hydroxy Toluene) and aluminium chloride were procured from Fluka.

\section{Sample extractions}

Extraction for phenolics, antioxidant activity and parthenolide analyses: $1 \mathrm{~g}$ leaf or flower samples were initially crushed in porcelain mortar and then transferred to durham bottle. $50 \mathrm{ml}$ methanol was added and mixed on magnetic stirrer for homogenization along 15 mins. Following homogenization, the samples were placed into ultrasonic-bath for $1 \mathrm{~h}$. Finally, the samples were centrifuged at 5000 rpm for 15 minutes [19].

Extraction for tryptophan, serotonin and melatonin analyses: $2 \mathrm{~g}$ dried plant material was crushed in porcelain mortar and homogenized on magnetic stirrer with $60 \mathrm{ml}$ solvent ( 2 methanol: $1 \mathrm{dd}-\mathrm{H}_{2} \mathrm{O}$ ) for 20 mins. Then, the samples were placed into ultrasonic bath for $1 \mathrm{~h}$ and incubated at $-20^{\circ} \mathrm{C}$ for two weeks. After this period, samples were sonicated for 30 mins. in sonic bath and then centrifuged for 10 mins. in $6000 \mathrm{rpm}$ at $4{ }^{\circ} \mathrm{C}$. Finally, supernatants of the extracts were used for HPLC analyses. Extractions were kept at $-80^{\circ} \mathrm{C}$ until used [30]. The study was carried out in dim light.

\section{HPLC analyses}

Separation of the compounds in the extracts was performed by a liquid chromatography system (HPLC) Agilent 1100 series(Agilent Technologies, Santa Clara, CA, USA) equipped with four Ecom pumps (Prague, Czech Republic), and a ACE C-18 column ( $5 \mu \mathrm{M}, 4.6 \mathrm{~mm} \times 150 \mathrm{~mm})$ coupled with a UV detector (Hewlett-Packard 1100 model). For phenolics and parthenolide analyses: Standards were prepared at 1.95-3.9-7.8-15.6-31.2-62.5-125-250$500 \mathrm{ppm}$ concentrations. Chlorogenic acid and cynarin were detected at 325 $\mathrm{nm}$; quinic acid was detected at $226 \mathrm{~nm}$. Mobile phase: Acetonitrile $20 \%$, dd$\mathrm{H}_{2} \mathrm{O} 80 \%$ with $0.05 \%$ trifluoroacetic acid and flow rate was $1.2 \mathrm{~mL} / \mathrm{min}$. Total analyses time was 35 minutes. Column heat was adjusted to $30^{\circ} \mathrm{C}$. The 
peaks corresponding to chlorogenic acid, cynarin and quinic acids were seen at $4.29 \mathrm{~min}, 19.06 \mathrm{~min}, 3.3 \mathrm{~min}$, respectively [16].

For parthenolide analyses: Mobile phase was isocratic including $55 \%$ acetonitrile $(A), 45 \%$ water $(B)$ per $22 \mathrm{~min}$ at $1.5 \mathrm{~mL} / \mathrm{min}$ flow rate. The peaks were analyzed at $210 \mathrm{~nm}$ with UV detector. The parthenolide peak was seen at 6.5. $\min [22]$.

For tryptophan, serotonin and melatonin analyses: Standards were prepared with 1.95-3.9-7.8-15.6-31.2-62.5-125-250 ppm concentrations. Mobile phase was $0.1 \%$ formic acid $+0.1 \mathrm{M} \mathrm{KH}_{2} \mathrm{PO}_{4}$ with dd- $\mathrm{H}_{2} \mathrm{O}(20 \%)$ and acetonitrile $(80 \%)$ per $35 \mathrm{~min}$ at $1 \mathrm{~mL} / \mathrm{min}$ flow rate. The peaks were analyzed at $280 \mathrm{~nm}$ with UV detector and column heat was adjusted to $28{ }^{\circ} \mathrm{C}$. Tryptophan, serotonin and melatonin peaks were seen at $4.1 \mathrm{~min}, 3.9 \mathrm{~min}$ and 17.6 mins. respectively. $20 \mu \mathrm{l}$ samples were injected to HPLC system. Before HPLC analyses, extracts were filtered with HPLC filter $(0.2-25 \mathrm{~mm}$ millipore). All injections were performed in triplicate.

\section{LC/MS-MS analyses}

Since melatonin peak was visualized at a very small rate, standard melatonin and two samples were run in LC-MS/MS (Zivak Tandem Gold) according to the method proposed by [26]. These assays were performed in order to support and verify HPLC analysis. The ionization techniques included electrospray ionization (ESI) and the optimized voltage was applied to monitor the precursor ions, mass fragments occur as molecular ions $(\mathrm{m} / \mathrm{z})$ are either $(\mathrm{M}-\mathrm{H})+$ or $(\mathrm{M}+\mathrm{H})+\mathrm{so}, \mathrm{m} / \mathrm{z} 232.28$ for melatonin, +1 and -1 ion charged form were determined in the chromatogram as 231.28 and 233.28 . According to this method, mobile phase involved $A-0.1 \%(\mathrm{~V} / \mathrm{V})$ formic acidacetonitrile, B- $0.1 \%$ formic acid $/ \mathrm{dd}-\mathrm{H}_{2} \mathrm{O}$, flow rate was adjusted $0.2 \mathrm{ml} / \mathrm{min}$, $5 \%$ A- 95\% B for the first $5 \mathrm{~min}, 35 \%$ A- $65 \%$ B for $30 \mathrm{~min}$, it was held for 5 min, $100 \%$ A-5 min, it was held for $5 \mathrm{~min}, 5 \%$ A- 95\% B-5 min, it was held for $5 \mathrm{~min}$. Total analysis time was set to $60 \mathrm{~min}$.

\section{Total phenolic compounds}

Total phenolic content was determined using Folin Ciocalteu reagent. $2 \mathrm{~mL}$ of Folin Ciocalteu reagent was added to the $400 \mu \mathrm{L}$ extract. After 3 mins, $1.6 \mathrm{~mL}$ of sodium carbonate $(7.5 \%)$ was added and the mixture was allowed to stand for $30 \mathrm{~min}$. Absorption was measured at $765 \mathrm{~nm}$ using a spectrophotometer (Agilent Rochester, NY, USA). A multipoint linear curve was obtained with gallic acid standard (Sigma) ranging from 20 to $400 \mathrm{ppm}$ $(y=0.0078 x+0.0763)$. The results were expressed as $\mathrm{mg} / \mathrm{g}$ GA [43]. 


\section{Antioxidant activity}

The antioxidant activity of extracts were determined using 2,2diphenyl-1-picrylhydrazyl (DPPH) radical scavenging activity. $1 \mathrm{mM}$ DPPH and the positive control BHT (1 mM) was dissolved in methanol. $100 \mu \mathrm{l}$ extract was poured into spectrophotometer baths and $3 \mathrm{ml}$ DPPH added to extracts and incubated at dark for $30 \mathrm{~min}$. Baths were read at $517 \mathrm{~nm}$ in spectrophotometer and calculated with the following formula; Radical scavenging activity: $\left\{\left(A_{0}-A_{1} / A_{0}\right) \times 100\right\}$. $A_{0}$ : DPPH solution, $A_{1}$ : extract with DPPH [43].

\section{Statistical analysis}

Three replications were used for each treatment. Data were expressed as mean and standard deviations. The means were compared using the oneway ANOVA followed by Duncan's multiple range tests. The differences between individual means were considered to be significant at $p<0.05$. Moreover, a principal component analysis (PCA) was performed in order to discriminate Tanacetum species on the basis of the components identified along with the study.

\section{ACKNOWLEDGMENTS}

This study was supported by grants from Kahramanmaraş Sütçü Imam University Scientific Research Projects Unit with 2013/4-20D project number. We would also like to thank Dr. Cihangir Uygun and Dr. İsa Başköse for their helps during collecting the plant material.

\section{REFERENCES}

[1] V. Kumar; D. Tyagi; J Pharmacogn. Phytochem., 2013, 2,159-63.

[2] M. Korkmaz; A. Kandemir; V. Ilhan; N. Yildirim Doğan; Turk. J. Bot., 2015, 39, 96-104.

[3] S.J. Murch; B.S. Colleen; K.S. Praveen; The Lancet., 1997, 350,1598-1599.

[4] Z. C. Arituluk; I. I. T. Çankaya; A. M. G. Özkan; FABAD J. Pharm. Sci., 2016, 41, 17-25.

[5] B. H. Kwok; B. Koh; M. I. Ndubuisi; M. Elofsson; C. M. Crews; Chem. \& biol., 2001, 8, 759-766.

[6] A. Ghantous; A. Sinjab; Z. Herceg; N. Darwiche; 2013, Drug Discov., 18, 894-905.

[7] R.R. Freund; P. Gobrecht; D. Fischer; H. D. Arndt; Nat. Prod. Rep., 2020, 37, 541-565. 
TRYPTOPHAN DERIVATIVES, PHENOLIC COMPOUNDS AND ANTIOXIDANT POTENTIAL ...

[8] M. Bahrami; M. Kamalinejad; S. A. Latifi; F. Seif; M. Dadmehr; Phytother Res., 2020, 34, 2429-2430.

[9] S.J. Murch; R.S. Krishna; PK Saxena; Plant Cell Rep., 2000, 19, 698-704

[10] R. Long; Y. Zhu; S. Zhou; Medicine., 2019, 98, e14099.

[11] Y. Yan; Q. Shi; B. Gong; Review of melatonin in horticultural crops, IntechOpen Book Series, London UK, 2020, 9, pp. 107-115.

[12] M. M. Essa; H. Hamdan; S. B. Chidambaram; B. Al-Balushi; G. J. Guillemin; D. M. Ojcius; M. W. Qoronfleh; Int J Tryptophan Res., 2020,13, 1-2.

[13] F. Pérez-Llamas; J. Hernández-Ruiz; A. Cuesta; S. Zamora; M. B. Arnao; Antioxidants., 2020, 9, 158-176.

[14] S. Agatonovic-Kustrin; D. W. Morton; Stud. Nat. Prod. Chem., 2018, 58, 61-91.

[15] M. D. Ferrari; K. I. Roon; R. B. Lipton; P. J. Goadsby; The Lancet., 2001, 358, 1668-1675.

[16] C. Wu; F. Chen; X. Wang; Y. Wu; M. Dong; G. He; R.D. Galyean; L. He; G. Huang; Phytochem Anal., 2007, 18, 401-410.

[17] S. Farzadfar; F. Zarinkamar; M. Hojati; Plant Physiol Biochem. 2017, 112, 207-217.

[18] A. Nieto-Trujillo; L. Buendía-González; C. García-Morales; A. Román-Guerrero; F. Cruz- Sosa; M.E. Estrada-Zúñigin; Rev Mex Ing Quim., 2017, 16, 371-383.

[19] D. Fraisse; C. Felgines; O. Texier; J.L. Lamaison; Food Nutr Sci., 2011, 2, 181-192.

[20] K. R. Hordiei, T. M. Gontova, A. G. Serbin, A. G. Kotov, E. E. Kotova; Ukr. biopharm. j., 2019, 3, 64-70.

[21] I. H. Gecibesler; A. Kocak; I. Demirtas; Nat. Prod. Res., 2016, 30, 2850-2855.

[22] I. Orhan Erdoğan; F. Tosun; A.R. Gülpınar; M. Kartal; A. Duran; F. Mihoğlugil; D. Akalgan; Phytochem. Lett., 2015,11, 347-352.

[23] S. Ozbilgin; E.K. Akkol; B. Ergene Oz; M. Ilhan; G. Saltan; O.B. Acikara; I. Suntar; Iran J Basic Med Sci., 2018, 2,145-152.

[24] M. B. Arnao, J. Hernández-Ruiz; Stud. Nat. Prod. Chem., 2015, 46, 519-545

[25] D. J. Kennaway; Food Funct., 2020, 11, 9359-9369.

[26] X. Huang, G. Mazza; Crit Rev Food Sci Nutr., 2011, 51, 269-284.

[27] M. H. Chung, T.S. Deng; Bot Stud., 2020, 61, 1-9.

[28] D. Ly; K. Kang; J. Choi; A. Ishihara; K. Back; S. Lee; J Med Food., 2008, 11, 385-389

[29] G. Chen; Y. Huo; D.X. Tan; Z. Liang; W. Zhang; Y. Zhang; Life Sci., 2003, 73, 19-26.

[30] M. Ansari; K.H. Rafiee; N. Yasa; S. Vardasbi; S.M. Naimi; A. Nowrouzi; Daru. 2010, 18, 173-178.

[31] A. Savcı; E. F. Koçpınar; Y. Alan; M. Kurşat; Int. Food Res. J. 2020, 27, 160170.

[32] M. A. Esmaeili; A. Sonboli; M. A. Noushabadi; Food chem., 2010, 121,148-155.

[33] A. Savcı; A. Yusuf; E. F. Koçpinar; M. Kurşat; S. Topdemir; M., Karataş; B. Çakmak; SDÜFEFFD, 2019, 14, 112-126.

[34] B. Tepe; A. Sokmen; Bioresour. Technol., 2007, 98, 3076-3079.

[35] İ. Emre; Braz. J. Biol., 2021, $81-1114$

[36] B. Kose; Y. Iscan; G. Goger; F. B. Demirci; C. Elmacı; Pak. J. Pharm. Sci., 2017, 30, 2047-2052. 
[37] S. Gharibi; B. E. S. Tabatabaei; G. Saeidi; S. A. H. Goli; M. Talebi; Ind Crops Prod., 2013, 50, 154-158.

[38] G. Zengin; A. Cvetanović; U. Gašić; A. Stupar; G. Bulut; I. Şenkardes; Ind Crops Prod., 2020, 146, 112-202.

[39] M. Topal; H. Gocer; F. Topal; P. Kalin; L. P. Köse; I. Gülçin; S. H. Alwasel; J Enzym Inhib Med Ch., 2016, 31, 266-275.

[40] K. Schütz; D. Kammerer; R. Carle; A. Schieber; J. Agric. Food Chem., 2004, 52, 4090-4096

[41] N. J. Jun; K. C. Jang; S. C Kim; D. Y. Moon; K. C. Seong; K. H. Kang; K. H. Park; J. Appl. Biol. Chem., 2007, 50, 244-248.

[42] A.J.C. Grierson; Tanacetum L. In: Davis PH, editor. Flora of Turkey and the East Aegean Islands, Vol. 5. Edinburgh, UK: Edinburgh University Press, 1975, pp. 256-292.

[43] P.H. Davis; Flora of Turkey and The East Aegean Island Vol. 5, Edinburgh Univ. Press., Edinburgh, 1965-1985.

[44] J. M. Fonseca; J.W. Rushing; N.C. Rajapakse; J. Appl. Hortic., 2008, 10, 36-39. 